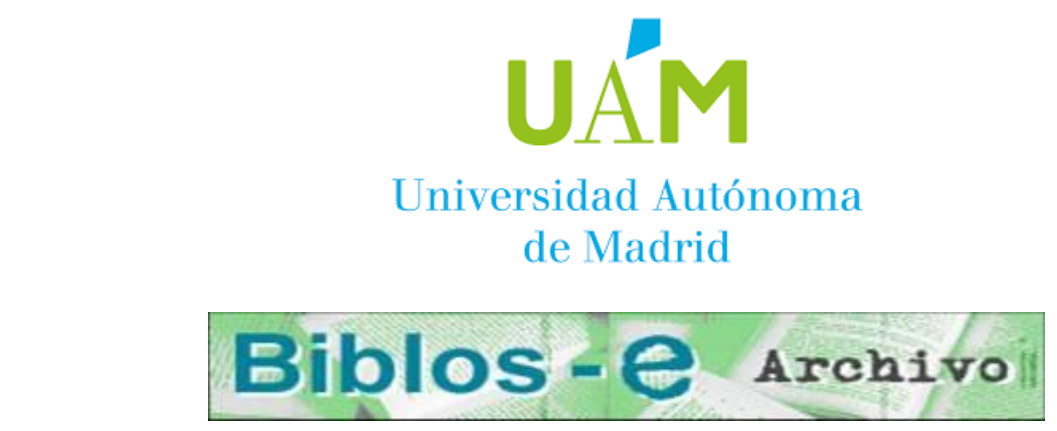

Repositorio Institucional de la Universidad Autónoma de Madrid https://repositorio.uam.es

Esta es la versión de autor del artículo publicado en:

This is an author produced version of a paper published in:

The European Journal of Development Research 25 (2013):

$584-599$

- DOI: https://doi.org/10.1057/ejdr.2013.25

Copyright: @ 2013 Palgrave Macmillan (part of Springer Nature)

El acceso a la versión del editor puede requerir la suscripción del recurso

Access to the published version may require subscription 


\title{
Oil in Chad and Equatorial Guinea: widening the focus of the resource curse
}

\author{
Artur Colom-Jaén \\ Department of Development Studies, SOAS, University of London, UK \\ Department of Applied Economics, Universitat Autònoma de Barcelona, Spain \\ Alicia Campos-Serrano \\ Department of Social Anthropology, Universidad Autónoma de Madrid, Spain
}

\begin{abstract}
The exploration and extraction of oil in the territorial sea of Equatorial Guinea and Chad's southern region of Doba have led to certain socio-economic and political dynamics among their populations. The literature developed around the concept of 'resource curse' is helpful in understanding how oil stimulates the governments' rentier behaviour and authoritarianism, as well as the countries' poverty and inequality. However, not all the similarities between the cases are explained by these approaches and some of the differences are relevant to understand the specific configuration of the curse in these countries. Only by taking into account historical trajectories, the particular strategies of local as well as non-local actors, and the international political economy in which oil is extracted and commercialised, can we properly analyse all these dynamics in their complexity.
\end{abstract}

Keywords: Equatorial Guinea; Chad; oil; resource curse theory; international political economy.

\section{Introduction $^{1}$}

In the last decade, the traditional flow of Foreign Direct Investment (FDI) to Africa linked to natural resources has dramatically increased, leading to what some scholars have named a "new scramble for Africa" (Carmody, 2011; Southall and Melber, 2009).

\footnotetext{
${ }^{1}$ An earlier version of this paper was presented at the AEGIS Congress 'Questions around the extraction of natural resources in Africa', 14 and 15 April 2011, Madrid.
} 
The broad context of this phenomenon includes the increase of the price of certain commodities, particularly oil; the rising demand for these commodities from emerging economies like China or India; the deployment of new geopolitical strategies of energetic supply by the US; improvements in the extraction technology which render profitable deposits that were not; and last but not least, the changes towards liberalisation in the regulatory frameworks of FDI that have occurred in most African countries.

The socio-political and economic effects of extractive industries in developing countries have been increasingly analysed. In this regard, there are numerous aggregated cross-country studies, as well as single-country case studies. ${ }^{2}$ This article intends to participate in these debates, comparing the particular experiences of two Central African newcomers in the global oil market.

Oil extraction is a recent industry in Chad and Equatorial Guinea, oriented to external markets and led mainly by US companies. It has created extractive enclaves in distinct geographies. Chad, with 11.5 million inhabitants, is a landlocked country, mainly Sahelian but with a well-endowed subtropical south. Chadian oil must cross Cameroon through a pipeline that ends at Kribi in the Gulf of Guinea. There, oil is shipped off the coast, in front of Bioko. This island is part of Equatorial Guinea, a much smaller tropical state with around 720,000 inhabitants, with a large exclusive economic zone in the surrounding sea, where oil reserves are being exploited offshore (see Figure 1). Equatorial Guinean crude is loaded directly into oil tankers that sail mainly to the US, along the same routes as those from Kribi. Since they both pour crude into the Gulf

\footnotetext{
${ }^{2}$ Since Sachs and Warner (1995), a prolific literature has developed this line of research (Wick and Bulte, 2009; Brunnschweiler and Bulte, 2008), including sophisticated econometric approaches in many cases, such as World Bank (2002) and Ross (2001 and 2009). A case for regional and comparative studies is made in Basedau (2005). Some regional studies are available such as Gary and Karl (2003) and Soares de Oliveira (2007). A specific comparative study on the effects of oil in Chad and Sudan is made in Behrends (2008).
} 
of Guinea they can be considered part of the same geo-economic region. Furthermore, they are also members of the Economic Community of Central African States (CEMAC), and share currency, the Central African CFA Franc.

Both cases have been analysed using the insights of the resource curse framework. ${ }^{3}$ This perspective, as we will see in the next section, highlights the connection between the extraction and exportation of mineral resources with enduring authoritarian political orders, bad developmental outcomes and economic stagnation. Our comparison is initially encouraged by the existence of explanations based on the resource curse approach in two countries where the authors had conducted fieldwork. We want to analyse to what extent the similarities that exist in both cases are explained by the resource curse theories, or are better understood taking into account alternative variables. At the same time, we will also investigate if dissimilarities put into question key assumptions of the resource curse theories. Our comparison has exploratory purposes, and its conclusions must be taken as consolidated hypotheses rather than hard findings.

A kind of non-developmental despotism has characterized political regimes in both places. In Equatorial Guinea, Obiang Nguema rose to power in 1979 overthrowing his uncle, Macías Nguema in a palace coup, whereas Idriss Déby conquered the presidency of Chad through a coup d'état in 1990. Since the end of the Cold War they have legitimated their positions in the international arena by celebrating presidential elections (in 1996, 2001, 2006 and 2011 in the case of Déby; and in 1996, 2002 and 2009 in the case of Obiang), but they actually remain in power thanks to the manipulation of the electoral processes and the extensive use of repression.

\footnotetext{
${ }^{3}$ See for example McSherry (2006), Gould and Winters (2011), Gary and Karl (2003) and Yates (2012).
} 
In spite of their large revenues inflows they remain included in the UN's Least Developed Countries category. Furthermore, Chad is ranked 183 out of 187 in the 2011 Human Development Index (UNDP, 2011). Even though Equatorial Guinea ranks 136 in the same classification, it is the country with the largest difference between its rank in GNI per capita and its rank in the Human Development Index (91 positions). ${ }^{4}$ Poverty is widespread in both countries, estimated in 2006 by the World Bank (2012) at 77 per cent of the population living below the national poverty line in Equatorial Guinea, and 55 per cent in Chad in 2003.

The pattern of development of the oil exploitation projects are similar in the chronology and the origin of the transnational companies involved, which are mainly US ones. In Chad, oil has been extracted since 2003 by a consortium of transnational companies (TNCs) led by ExxonMobil, in a project that constitutes the single biggest private investment in Sub-Saharan Africa. Oil production in Chad was approximately 115,500 barrels per day (bpd) in 2011, having peaked in 2005 with 173,000 (see Table 1). In the case of Equatorial Guinea, different joint ventures led by Marathon, Hess and ExxonMobil have been in charge of oil extraction since 1996. In 2011, its production was $252,000 \mathrm{bpd}$, and it peaked in 2005 with $358,000 \mathrm{bdp}$. It remains the fifth largest African oil producer, only behind Nigeria, Angola, Sudan and the Republic of Congo (BP, 2012).

In the following section we will use some of the resource curse insights to understand the internal dynamics prompted by oil extraction in both countries. Our aim is to investigate to what extent the consequences of oil production in Chad and Equatorial Guinea can be explained using this framework, and to identify what is needed in addition to explain the specific outcomes. In the third and central section of

\footnotetext{
${ }^{4}$ This surprising feature can be explained because the GNI per capita is very high $(17,608$ international $\$$ in PPP) due to a huge inflow oil rent coupled with a small population.
} 
the article we will show how a perspective that takes into account the particular historical trajectories, the role of non-local actors, and the international political economy of oil, explains better the specific socio-economic and political outcomes that oil extraction produced in Chad and Equatorial Guinea, as well as some of the features they share.

\section{What resource curse approaches illuminate in Chad and Equatorial Guinea}

\section{The Dutch disease approach}

The so-called 'Dutch disease' approach argues that the appreciation of the real exchange rate due to massive entries of foreign currency hurts the tradable non-mineral sectors, because their relative prices worsen vis-à-vis the rest of the world, thus becoming less competitive (The Economist, 1977; Corden and Neary, 1982).

In Chad, the production of cotton and livestock oriented to export were in decline and progressively being substituted by food crops when oil exploitation started in 2003 . Thus, Chad's stagnant competitiveness in non-oil sectors is better explained by changing cotton international prices and persisting productive constraints, such as low level of infrastructure development (Nachega and Wieczorek, 2012: 36). Extraction does have other socio-economic consequences: the instalment of a shanty town in the village of Komé, next to the main operational facilities of the oil consortium, has attracted people in search of employment related to the local oil industry, prompting prostitution and the spread of HIV/AIDS. Employment creation in the area has been limited and temporary in many cases, agriculture yields have deteriorated because of pollution, and other serious environmental impacts are harming the health of the local populations (Reyna, 2007, p. 82-85). 
The main cash crop in Equatorial Guinea, cocoa, was already declining when oil was discovered, but agriculture activities oriented to subsistence or local markets have also suffered a setback in recent years, and food is mainly imported from neighbouring countries such as Cameroon. The appreciation of the currency is not the sole cause of these uneven effects, as the Dutch disease approach would suggest. The regional character of the CFA Franc and its link to the euro guarantees a certain degree of monetary stability regardless of domestic circumstances. The aforementioned effects on the food sector or the general rise in the cost of living experienced in the country must be related to other social and economic dynamics such as the large migration flows to the towns from rural areas and neighbouring countries prompted by oil industry.

In our cases, some of the socio-economic outcomes related with oil exploitation are not explained by the Dutch disease theory. That takes us to the second theoretical strand of the resource curse framework, derived from political economy approaches.

\section{The rentier-state approach}

Starting with the work of Mahdavy (1970), this approach maintains that the low growth rate observed in countries with an abundance of natural resources is due to the existence of an external rent. This rent feeds corruption, waste of money, large and expensive projects with little productive sense (white elephants), and rent-seeking behaviour. Furthermore, if such a rent gives a sufficient fiscal base to the government, it has no need to tax the population, thus weakening the social contract between citizens and state. In this situation, public finance controls loosen and the government does not have an explicit obligation to meet social demands with public spending. Thus, the personal enrichment of the élite, as well as its preservation in power, would prevail over other 
political goals (Beblawi and Luciani, 1987; Yates, 1996; Karl, 1997 and 2005; Ross, 1990 and 2001; Auty 1993 and 2008; McFerson, 2009).

These dynamics are visible in our two cases. In Equatorial Guinea, individuals in government accumulate most of the rents paid by companies through different mechanisms such as the direct payments of oil rents to private bank accounts, or the constitution of local companies in order to sign joint ventures with oil TNCs (Frynas, 2004, US Senate, 2004; Wood, 2004; McSherry, 2006; Shaxson, 2007). Oil has also empowered the government with new instruments of social control such as those developed through labour relations. In Equatorial Guinea, employment agencies owned by the President's relatives, ensure that no political dissident gets a job in the oil sector (Campos and Micó, 2006). The clientelistic distribution of oil rents appears to be a conscious policy of the government in order to prevent the emergence of a middle class, and a stronger opposition movement. In fact, the political opposition suffers the politics of repression, cooptation and fragmentation that oil rents enable, while investment in health, education and sanitation remains scarce. ${ }^{5}$

In Chad, the oil rent that flows to the country since 2003 has significantly empowered Déby and his clientelistic entourage. Since the beginning of the oil project's construction phase in 2000 , an important proportion of the contracts associated with it and lateral programs financed by the WB, have favoured the president's entourage through companies focused on delivering services to the construction and oil companies. As in Equatorial Guinea, the rent has also served to consolidate their power

\footnotetext{
${ }^{5}$ Among the main political parties of the opposition we find the social-democrat Convergencia Para la Democracia Social (CPDS), the more liberal-right wing Unión Popular (UP) and Alianza Popular de Guinea Ecuatorial (APGE), and the Frente Democrático Republicano (FDR), whose social bases are found in the same area as the Nguema family (Mongomo). Now in exile, there are also the Partido del Progreso (PP); and the Movimiento de Autodeterminación de la Isla de Bioko (MAIB), which defends a secessionist project for the island.
} 
through reinforced authoritarianism (Magrin, 2003; Gould and Winters, 2011; Gary and Reisch, 2004; Massey and May, 2005 and 2009; Petry and Bambé, 2005).

\section{Oil and internal conflict}

In the Chadian case the oil rent has fuelled armed conflict as well. In 2005 an armed rebellion born in the innermost circle of the President, established itself in the Eastern part of the country and launched successive attacks on the capital N'Djamena in April 2006 and February 2008. Apparently, the rebels' uprising was a reaction against the modification of the constitution carried out by Déby in 2006, in order to be eligible for re-election that same year. That was perceived as a move to block the possibilities of competing for succession and to have direct access to the oil rent (Gould and Winters, 2011; Massey and May, 2006 and 2009; Pegg, 2009). In Equatorial Guinea, the Nguema family seems to maintain tighter control of the political and economic mechanisms of the country. However, the government suffers periodical menaces from abroad: different armed groups, from South Africa or the Niger Delta have attacked the country in 2004, 2007 and 2009 (Ghazvinian, 2007; Shaxson, 2007; Güell, 2009).

These violent dynamics have also been analysed using the rent-seeking argument, correlating resource abundance and armed conflict. According to Paul Collier and other scholars, mineral resource extraction raises the probability of generation and persistence of violent conflicts, because of the predatory and 'greedy' behaviour of politicians and militia fighters, who see the conflict as an opportunity to gain access to resources that otherwise would be out of their reach (Collier and Hoeffler, 1998 and 2004; Ross, 2004). 
The resource curse approach illuminates some of the logics underlying the domestic political and economic dynamics in both Chad and Equatorial Guinea. However, the shortcoming of this approach is that it does not analyse in detail the effects of oil extraction in each country. Furthermore, although these theories convincingly explain the rentier behaviour of governments, they do not clarify why these governments, and the particular individuals behind them, benefit most from oil wealth. The resource curse approach does not help to understand the obvious continuities displayed in the way power and control is exercised, before and after oil discoveries in both countries. Finally, if greed is one explicit reason to fuel insurgence or armed attacks, as the economic approach to war points out, the longer history of grievances and conflicts in these cases receives scant attention.

Some scholars have pointed out some of these shortcomings. Di John (2007) highlights that the corruption and authoritarianism present in many oil-exporting countries are better explained by previous political dynamics. Brunnschweiler and Bulte (2008) make a distinction between 'resource abundance', and 'resource dependence'. Whereas the resource curse approaches take 'resource abundance' as the share of mineral exports to total exports, or the share of mineral-related production to total production, these are, rather, proxies for 'resource dependence'. This is a more meaningful concept for the political economy of development, related to a particular economic structure produced by history and power relations. In Wick and Bulte (2009) the case is made for paying attention to institutional quality as a conditional factor of the curse and some scholars even suggest, like Haber and Menaldo (2011), that in the long run resource abundance might be a blessing in terms of developmental outcomes. Regarding the violence that natural resources may produce through rebellions led exclusively by greed, Cramer (2002) argues that in the real world wars cannot be 
explained by rent-seeking reasons: there are grievances, ideologies and collective actions difficult to explain with the neo-classical approach that underpins the mainstream theories.

Our contribution emphasises the need to widen the focus to include dimensions and actors poorly taken into account by the resource curse approaches, in order to understand the specific relation of oil extraction with poor developmental outcomes, authoritarianism, corruption and violence in Chad and Equatorial Guinea.

\section{Oil extraction in context: widening the focus of the resource curse}

Three dimensions, closely related to each other, are necessary to better understand the construction of the particular curse suffered by most of the population living in Equatorial Guinea and Chad. These dynamics refer to the particular historical trajectories of both territories, the role of some non-local actors (particularly TNCs), and the international political economy of oil extraction.

\section{Common and particular historical trajectories}

As in the rest of the continent, the end of colonial rule brought in both cases the international recognition of sovereignty and the emergence of new independent states. The principle of sovereignty conferred on the new governments the legal representation of the state and the capacity to negotiate internationally, regardless of their legitimacy and representativeness among the local population. According to Bayart (2000), the acquired sovereignty did not change the extraverted nature of colonial power in the continent, and dependence on external resources became the main basis of the ruler's control over the population. 
Since then, new governments have obtained resources from their role as 'gatekeepers' between the population and international markets and donors (Cooper, 2002). Continuity with colonial economy was more obvious in Chad, as cotton persisted as the main export. In independent Equatorial Guinea, cocoa production, along with coffee and timber, dramatically declined after the expulsion of Spanish owners and Nigerian workers by Macías Nguema's government (Fegley, 1989; Sundiata, 1990). Aid from the former metropolis (Spain for Equatorial Guinea and France for Chad) and other donors helped to maintain weak administrations and autocratic leaders in power. In Equatorial Guinea, aid flows during the 1980s, especially from Spain, increased as the government realigned with the Western side of the Cold War. At the same time, export of timber became a new source of income for the state. Whereas in Chad, French influence has been very strong from the beginning, particularly evident in the significant military presence in the country.

In both countries power has been exercised in a very authoritarian manner by the governments, which are occupied nowadays by two army officials: Obiang Nguema and Idriss Déby. As we have mentioned, they took office after toppling their predecessors in 1979 and 1990 respectively, long before oil extraction commenced. The end of the Cold War brought constitutional changes in most of Africa, as well as new discourses on behalf of the donors in favour of democracy and human rights. However, though periodic elections are celebrated since the 1990s, they are systematically flawed and manipulated. Personal ties count more than institutions and formal regulations in the relations between authorities and population; and human rights violations are one of the main tools of political control.

Obiang Nguema's internal constituencies are mostly his own family from the Eastern region of the continental territory (Mongomo district), which has controlled the state 
since independence (Fegley, 1989; Linigier-Goumaz, 1996). His relatives occupy the highest ranks of the Army and most of the public administration. Territorial officials belong to the incumbent party (Partido Democrático de Guinea Ecuatorial, PDGE). In spite of occasional violent attacks from abroad, with minor participation of individuals inside the country, the government maintains a strong command over the population, which allows it to boast internationally about the stability in the country (Nzang, 2009; Sant, 2008).

In Chad, key positions in the network of power, including the Army, also belong to the closer circle of Déby, many of them from the Zaghawa clan, from the East. Déby's control over the whole territory is, however, looser than Obiang's. ${ }^{6}$ Nowadays it is possible to find either Muslims or Christians everywhere in the country, but the ethnic and geographic cleavage between the traditionally Muslim North and East and the mostly Christian and animist South, has shaped Chadian political history. During the 1980s and 1990s, after oil discoveries, violence was widespread in the Doba basin between Habré's and Déby's government, and Southern militias (Reyna, 2011, p. 147151).

Rebellions erupted again in Chad in 2005, and seriously challenged central government until 2008, when thanks to oil wealth and international support mainly from France, Déby has been able to build a powerful army capable to quell uprisings. ${ }^{7}$ This

\footnotetext{
${ }^{6}$ Some scholars have considered that during the 1980s Chad was a virtual failed state (Buijtenhuijs, 1998; Azevedo, 1998).

${ }^{7}$ In February 2008, at the time of the most serious attack on N'Djamena, three groups comprised this alliance: the Union des Forces pour la Démocratie et le Développement (UFDD), lead by Mahamat Nouri, an ancient Déby minister; the Rassemblement des Forces pour le Changement, led by Timan Erdimi; and the UFDD-Fondamentale, constituted by a group of former members of the UFDD, led by Abdelwahid Aboud Mackaye, as well a former collaborator of Deby. From that moment on, rebellion faded because of the co-optation politics of Déby, and the cited huge increase of military power of the Chadian army financed by the oil rent. At the end of 2008 a new alliance was set up, the Union des Forces pour la Résistance (UFR), with material support from the Sudanese government. However, the peace agreement between Sudan and Chad in January 2010 has undermined the UFR, and currently they have no real probability of defeating Déby militarily (Hansen, 2011; HSBA, 2011).
} 
time, rebellions came from the East and were born in the close circles of Déby, including members of the Zaghawa clan. Even though access to the oil rent might have been a reason to start rebellion in 2005 , it cannot be fully explained without reference to specific grievances like those suffered by the Tama people of northeastern Chad (Behrends, 2008, p. 49; Reyna, 2007, p. 85-87). There have also been strong international connections with the Sudanese conflict in Darfur (de Waal, 2008). Moreover, uprisings within the group in power seems to be a common device in the pursuit of power in Chad: Déby himself held key positions in the Army with Hissène Habré before organising a rebellion in 1989 that managed to oust Habré from government in 1990.

The current supremacy of Déby and Obiang and their authoritarian exercise of power can be explained as products of oil rents, since these rents allow them to acquire the necessary means to settle their authoritarian system, to corrupt or co-opt the opposition and to face rebellions with success. Nevertheless, there is a history that began long before oil discoveries. This history includes shared experiences such as the European colonial domination, which configured both territories in terms of dependency to the far away metropolis. The postcolonial political elite did not manage to structurally transform the extraverted nature of the colonial administration, and the state was built on a patrimonial rationale, rather than a bureaucratic or developmentalist one. This also explains why, when oil was discovered, these countries lacked both the technical capacity and the social setting to be able to take advantage of the oil industry.

Oil discoveries and extraction amplified, rather than maintained or drastically transformed, certain old authoritarian and impoverishing phenomena. At the same time, oil exploitation halted some more recent trends, such as the political reforms initiated in 
the early nineties. The arrival of oil TNCs and other investments related to oil reduced the effectiveness of the wave of political reforms in these countries.

\section{Non-local actors in the oil era}

The resource curse theory makes visible populations 'cursed' by the extraction of minerals, and identifies the local elites and governments as the main beneficiaries and proponents of the rentier dynamic. Nevertheless, if minerals constitute an external source of rents it is because they become valuable and are commercialised somewhere far away. The process of transforming underground oil into government rents is, therefore, a transnational one in which oil TNCs play a central role. This is especially true in many African countries, such as Equatorial Guinea and Chad, where technical and financial capacities were non-existent at the time of oil discovery, and the development of the oil industry was made by TNCs, mainly from the US in these cases.

In 1992, Walter International Inc., owned by the former US ambassador in Equatorial Guinea, Chester Norris, made the first offshore discoveries near Malabo. ${ }^{8}$ Other US companies followed, led by Marathon, Exxon-Mobil and Hess Corporation, which signed sharing contracts with the government. Today, these agreements include joint ventures with parastatal GEPetrol and other private companies from all around the world including the Energy Africa (UK), Sasol (South Africa), Petronas (Malaysia), Roc Oil (Australia), CNOOC and CNPC (China), and Repsol (Spain).

In 1988 a Convention Agreement was signed between Chad's government and a Consortium of three companies (Chevron, ExxonMobil and Shell). This Convention granted a 30-year concession of exploration and exploitation around the area of Doba.

\footnotetext{
${ }^{8}$ Authors who pay particular attention to oil companies in Equatorial Guinea and Chad are Ghazvinian (2007) and Harel (2006).
} 
ExxonMobil through its subsidiary EssoChad assumed the operational leadership. The Consortium was restructured two times, and when operations commenced in 2000, the participants in the Consortium were Exxon Mobil (40\% stake), Petronas (35\%), and Chevron (25\%). At the same time, two public companies were constituted to manage the pipeline: TOTCO (Tchad Oil Transport Company) and COTCO (Cameroon Oil Transportation Company) (Pegg, 2005). ${ }^{9}$

Soon after extraction began in both countries, oil revenues paid by the aforementioned TNCs became the main component of the respective countries' budgets. They reached 63.3 per cent of the total revenue in Chad in 2010, and 92.4 per cent in 2009 in Equatorial Guinea (see Table 1). Nevertheless, TNCs are not only the actual providers of rents: they also participate in the private appropriation made by the individuals in government, and in the social fabric of the resource curse in different ways, such as by paying minimal compensation for ancient trees that were chopped down to construct the oil fields in Doba (Petry and Bambé, 2005).

In Equatorial Guinea, relations between companies and government account for many legal and illegal, public and secret, exchanges such as the payment of Obiang Nguema's lobby in Washington, the concession of scholarships to Nguema's children in the US, the renting of buildings and plots owned by the Nguema family, or the contract of workers through labour agencies controlled by Obiang relatives (US Senate, 2004; Campos and Micó, 2006). Furthermore, oil companies directly facilitate the diversion of public funds and the personal enrichment of officials. In 2004, a US Senate report denounced the payments made by US oil companies to numerous bank accounts in the Riggs Bank, based in Washington, controlled by Obiang Nguema and some few close relatives (US Senate, 2004; Global Witness, 2004). Foreign companies in sectors other

\footnotetext{
${ }^{9}$ For a broader background of the oil project in Chad, see Gary and Reisch (2004), International Crisis Group (2009) and Colom (2010 and 2012).
} 
than oil, such as construction, have signed joint ventures with individuals holding positions in the government or close to them. These partnerships provide the domestic political elites with exclusive ways of accumulating wealth and power.

Foreign governments have also reinforced relations with Malabo. Condolezza Rice received the Equatorial Guinea president in 2006 in Washington as a 'good friend of America' (The Washington Post, 2006). High officials from China or Brazil, among others, are keen to develop economic and diplomatic relations with Malabo. President Obiang has significantly expanded his presence and leverage in regional and international fora, thanks to foreign interests related to oil. ${ }^{10}$

In Chad, the role of oil companies has evolved following strategic French and US interests in the country. At independence, in 1960, the French government made sure that an agreement was reached to ensure that mineral resources in the country would not be developed without their consent and the involvement of Elf (the French oil parastatal). In 1969 the then-president Tombalbaye got rid of Elf and turned to the US firm CONOCO, which successfully found oil in 1971. Many think that the coup d'état that overthrew Tombalbaye in 1975 was at least partially related to this fact (Reyna, 2011, p. 143).

In 1982 Hissène Habré reached power thanks to the financial and logistic support from France, but more crucially from the US. ${ }^{11}$ So, not surprisingly the Convention Agreement of 1988 involved two US companies. France reacted by supporting Déby and his coup d'etat against Habré, in what some have labelled as a 'coup d'État militaro-

\footnotetext{
${ }^{10}$ However, transnational NGOs, media and even judicial and legislatives bodies such as those in US, France or Spain have tried to scrutinise the agreements between government and oil companies and the destination of oil rents (US Senate, 2004; Silverstein, 2012; Amnesty International, 2009; Global Witness, 2004 and 2009; EG Justice, 2012; Human Rights Watch, 2009).

${ }^{11}$ The deplorable human rights record of that time is in part the responsibility of the Direction de la Documentation et de la Securité (DDS), a unit which had US support (Reyna, 2011, p. 144; Amnesty International, 2001).
} 
pétrolier Elf' (Reyna, 2011, p. 145). As a consequence, two years later Déby forced the entry of Elf into the Consortium to the detriment of Chevron. Although Elf left the Consortium in 1999, the project's construction phase started the following year and benefited many French firms. In October 2003 oil extraction commenced several months ahead of schedule and the first exports to the US were recorded. ${ }^{12}$ French and US interference has continued ever since: when the last major rebel attack took place in February 2008, and Déby was about to be toppled, only an external French intervention prevented this from happening (Bayart, 2008, CCFD, 2012)

In the case of Chad, other transnational actors are crucial to understanding the political economy of oil. Beyond its modest financial contribution, it was the WB who established the legal grounds that guaranteed the flow of benefits to the investing companies without fear of expropriation. Nevertheless, the most visible feature of the WB involvement in Chad was the establishment of a policy framework intended to avoid the resource curse through good governance (Humphreys et al., 2007, Arezki et al., 2011). At the request of the WB, the national parliament passed in 1999 the Loi $001 / P R / 99$. This law established that out of the total direct revenues (royalties and dividends), 10 per cent had to be allocated to the Fonds pour les Générations Futures, and 90 per cent to the national treasury, mostly for social expenditure. ${ }^{13}$ At the same time the government had to undertake the process of formulating a Poverty Reduction

\footnotetext{
${ }^{12}$ The reasons behind Elf's decision remain unclear. The official explanation offered by Elf stated that the profitability of the project was dubious. Other sources say that since Elf at that time was under investigation for corrupt practices in France, the company intended to avoid further scandal by not getting involved in a project with such a complex setting. This last reason explains why Shell also left the project (Reyna, 2011, p. 145).

${ }^{13} 80$ per cent of this had to be allocated to the sectors considered poverty reducing, the so-called priority sectors (health, social affairs, education, infrastructures, rural development, environment and water resources), 15 per cent to the functioning of the government and 5 per cent to the oil region (Logone Oriental).
} 
Strategy Paper (PRSP). Finally, in June 2000 the WB board approved the project and begun its execution. ${ }^{14}$

Despite the strong 'good governance' component of the WB involvement in the Chadian project, it has not prevented the government's rentier behaviour. The Fonds was cancelled at the end of 2005, and the money was allegedly used to expand military spending in a context of armed rebellion and increasing insecurity (Gould and Winters, 2011). The WB position, between the interests of the TNCs and the government, was hard to maintain and in fact it had to abandon the project in September 2008 (Reyna, 2007; Pegg, 2005 and 2009; Winters and Gould, 2011).

In sum, the configuration of the curse is always a matter of two or more parts. In an oil economy, rentier behaviour on the part of governments cannot be properly explained without the profit logic of the private companies. On the other hand, some of the divergences we perceive between our two cases are in part product of the differences in the transnational actors involved and their particular relationship with local ones. The political economy of oil in Chad and Equatorial Guinea is therefore shaped by the interests and strategies of many actors, which work in contexts that go beyond national territories. It is to these broad contexts that we turn our attention now.

\section{The rules of the international political economy}

None of the local or transnational actors that we have mentioned act according to their interests in a structural and institutional vacuum. Certain features and dynamics of the

\footnotetext{
${ }^{14}$ The Loi also established a body to control spending, the Collège de Contrôle et Surveillance des Ressources Pétrolières. This body's purpose was the management of the revenues allocated to the priority sectors. Members of the College were appointed by the government, as well as by civil society through previously designed NGOs (Gould and Winters, 2007; Kojucharov, 2007). To complete the institutional setting, the first PRSP was finally approved in 2004 within the framework of the Heavily Indebted Poor Countries Initiative promoted by the WB and IMF. A second PRSP was launched in 2008.
} 
world economy are fundamental to understand the way those interests are pursued, and the effects they have on the political economy of oil in each place. The international institutional arrangements of oil extraction are shared by all oil producing countries and explain in part the common patterns stressed by the resource curse approaches.

In our cases, oil exploitation began in the context of a growing demand. Since the First Gulf War (1991), the oil supply strategy of the USA has been to diminish its oil dependence vis-à-vis the Middle East, by getting oil from other locations, such as the Gulf of Guinea (Obi, 2009). On the other hand, the thirst for energy sources and other minerals by emerging economies in Asia, led to increasing prices of strategic commodities and boosted investments in the extractive sectors from countries such as China.

At the same time, the structural adjustment policies that have been promoted since the 1980s included the generalisation of legal provisions that eased the entry of FDI, such as economic integration treaties, bilateral free-trade agreements, or the multilateral negotiations at the World Trade Organization level (Gibbon, 2002; Wade, 2003). In Africa and other developing areas, this led to the concentration of investments in the raw materials industries, and the abandonment of active industrialisation strategies.

During the 1990s, the WB and the IMF devised a reformed version of the "minimal state' model brought by the structural adjustment programmes which emphasised governance (Harrison, 2004). That 'good governance matrix' promoted poverty reduction policies and anticorruption legislation in order to legitimate the neoliberal programme of deregulation (Carmody, 2009). At the same time, Sovereign Wealth Funds were promoted in many natural-resource rich countries with the explicit aim of avoiding the resource curse, and supporting active long run economic policies (IMF, 2011). 
We have already seen how the WB conditioned its support to the Chadian project to changes in the legislation and the establishment of the Fonds pour les Générations Futures and a PRSP. In Equatorial Guinea no such intervention of international organisations ever happened, though their desire for international acceptance explains the adoption of some formal measures. A new hydrocarbons law was approved in 2006, along with a Fund for Future Generations, and a National Plan for Economic and Social Development the following year, after a second National Economic Conference (Government of Equatorial Guinea, 2006). These funds neither avoid the diversion of public money to the political elite nor promote structural change or social expenditure, but governments and companies wield them in order to legitimate their participation in the oil industry.

As we can see, oil markets are not only defined by the logic of demand and supply, but also by institutions, too often concealed in analyses. One of the institutional features of oil markets is the central role played by the sovereign state, even in contexts such as Chad and Equatorial Guinea where oil operators are foreign TNCs and the regulatory capacity of the state is weak. International and national legal sovereignty conventions, developed during the decolonisation process, consider the state the legitimate owner of the natural resources under the soil and those who occupy the government its legal representatives with capacity to carry out negotiations concerning these resources. The huge capital investments required in the oil industry make companies eager to deal with state officials, who work as true gatekeepers, rather than with any other local group or authority (Reno, 2000 and 2001; Cooper, 2002).

Another feature of the world economy is that the global financial system is organised in such a way that allows legal and illegal capital flight (Shaxson, 2011). The existence of private financial institutions, some of them based not only in tax havens but also in 
Western (and increasingly in other countries') territories, allows rentier governments to keep oil revenues away from the national treasuries. The scandal of the Riggs Bank is a case in point. Part of the money poured into the Nguema family's accounts by US oil companies seems to have been used to buy personal estates in the US and Spain, in this case through money transfers to Banco Santander (Open Society, 2009).

Finally, the rentier behaviour of governments regarding mineral wealth cannot be understood without considering the structural inequality among regions that characterises the world economy. It is because the Gulf of Guinea's population lacks the consumer capacity of those people in other places, and, to a lesser extent, the entrepreneurial and technological capacities to take advantage of the wealth under their soil, that other people far away become the main buyers and beneficiaries of it and governments can develop the rentier behaviour that lies behind the resource curse. This reality may be deepening following the same dynamics that we are analysing here, since a rentier economy in cases such as Equatorial Guinea and Chad also blocks poverty reduction.

In any event, neither the governments of Chad and Equatorial Guinea, nor the US and other involved oil companies, can claim to be mere victims of these international institutions and structures. To a greater or a lesser extent, all of them play a role in the construction and maintenance of this unequal system, which politically fragments the world in different sovereignties and, at the same time, guarantees the free movement of capitals. 


\section{Concluding remarks}

A close look at the specific cases of Chad and Equatorial Guinea shows that many common features such as authoritarianism, conflict, poverty and underdevelopment are shaped by the oil rent. How this rent empowers both governments vis-à-vis their impoverished population and fuels conflict is well described by the resource curse approaches. Obiang Nguema and Idriss Déby are able to pursuit their political agendas thanks to the oil rent, which enables them to crush and co-opt the opposition and hold on in power, as well as to enrich themselves and their closer circle. The fiscal irrelevance of the local population explains in great part the absence of social policies and redistributive mechanisms based on the oil revenues.

However, these common dynamics are not the result of a universal pattern created by oil exploitation at any given time or place. On the contrary, they are only intelligible as a consequence of particular historical trajectories and a specific way of insertion in the world economy. Both countries share a history of colonialism, decolonisation and extraversion that explain why oil rents would play a similar role when oil was discovered. On the other hand, differences in the effects of oil, such as the fuelling of armed conflict in Chad but not in Equatorial Guinea, cannot be explained without reference to the local forms that relations between groups adopted in both places during the construction of the colonial and postcolonial state, long before oil discoveries.

If oil rents reinforce authoritarianism and block development prospects it is also because certain features of international markets and institutions ensure that oil extraction benefits some particular social groups and harms many others. How oil acquires value and how this value circulates worldwide, affecting population above or near the oil fields is not a product of the intrinsic features of minerals, but of socially constructed economic and political relations. In this article, it has been necessary to 
broaden our understanding of historical and transnational processes in order to explain the shared features apparent in both countries, which cannot be considered mere products of oil extraction.

The resource curse approaches illuminate only a portion of a complex process, which is transnational in nature and connects, in very unequal ways, geographically distant groups and areas of the world. If there is a curse for many of the people living in the extracting areas, there are other people blessed by the black gold: without this blessing it would not be possible to understand the construction of the political economy of oil. The intermediary groups, in our cases those who occupy the local governments and the (mostly US) TNCs, are the major beneficiaries of this unequal exchange among regions. Only by paying attention to international institutions such as the sovereignty principle, and to some specific features of extractive activities, can we understand that the relations between those who live near the resources and the final consumers of oil are strongly mediated by a small number of individuals: those who possess the means of production necessary to exploit the resource, and those who occupy the government.

In sum, to explain the authoritarianism and the obstacles to human development and structural change in Chad and Equatorial Guinea, we have found it necessary to look at those aspects barely taken into account by the resource curse approaches. We have explored the socio-political and economic framework shaped by history and the international political economy before the arrival of oil rents, and we have found that these features in both cases are significant in order to explain the specific outcomes of oil exploitation.

Our conclusion goes beyond our two cases and serves as a consolidated proposition for further research to reassess the resource curse hypothesis by taking into account the 
particular trajectories of every case, and structural issues such as the unequal integration of producing areas in the world economy. 


\section{Graphics}

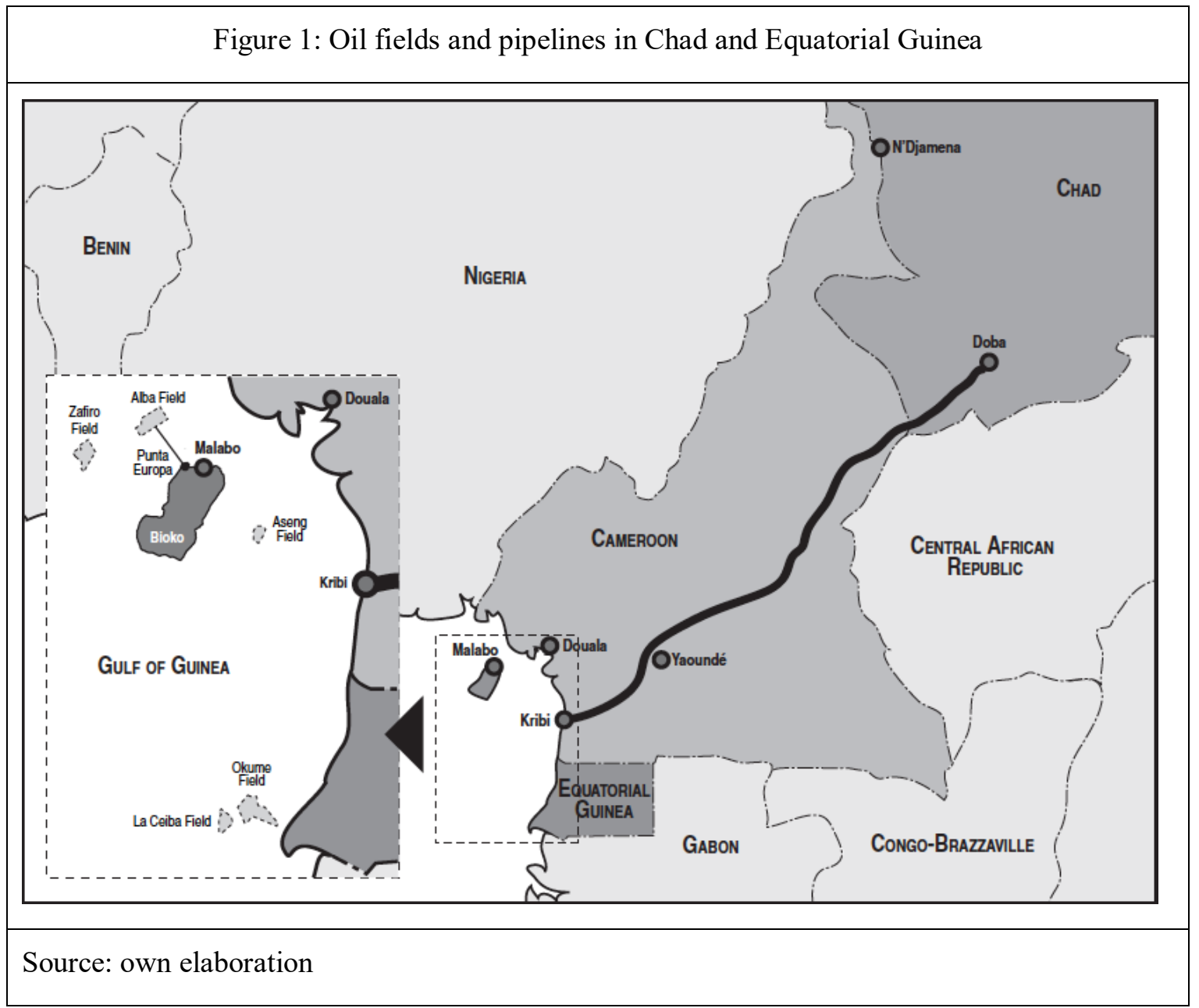

\begin{tabular}{|c|c|c|}
\hline \multicolumn{3}{|c|}{ Table 1. Chad and Equatorial Guinea, basic data } \\
\hline & Chad & Equatorial Guinea \\
\hline Human Development Index (2011) (a) & $0.328\left(183^{\text {rd }}\right.$ out of 187$)$ & $0.537\left(136^{\text {th }}\right.$ out of 187$)$ \\
\hline GNI per capita (constant 2005 PPP \$) (2011) (a) & 1,105 & 17,608 \\
\hline Life expectancy at birth (years) (2011) (a) & 49.6 & 51.0 \\
\hline Share of oil revenue in total revenue (per cent) (b) & $63.3(2010)$ & $92.4(2009)$ \\
\hline Hydrocarbons production (2010) (1) & $122,500 \mathrm{bpd}(\mathrm{c})$ & 434,500 boe $(b)$ \\
\hline Share of oil sector in GDP (per cent) (b) & $21.6(2009)$ & $53.6(2010)$ \\
\hline Share of oil exports in total exports (2010) (b) & 89.2 & 98.8 \\
\hline \multicolumn{3}{|c|}{$\begin{array}{l}\text { Note: (1) since Equatorial Guinea produces both gas and oil, we use the unit 'boe' (barrels of oil } \\
\text { equivalent) to measure its total production, instead of 'bdp' (barrels per day). }\end{array}$} \\
\hline \multicolumn{3}{|c|}{ Sources: (a) UNDP; (b) own calculations from IMF data; (c) EssoChad, Project Update \#29 } \\
\hline
\end{tabular}




\section{References}

Amnesty International. (2001) Tchad: l'héritage Habré, AFR 20/004/2001.

Amnesty International. (2009) 'Equatorial Guinea: Submission to the UN Universal Periodic Review Sixth session of the UPR Working Group of the Human Rights Council', AFR 24/002/2009. London.

Arezki, R., Gylfason, T. and Sy, A. (2011) (eds.) Beyond the Curse. Policies to Harness the Power of Natural Resources. Washington DC: IMF.

Auty, R. (1993) Sustaining Development in Mineral Economies: The Resource Curse Thesis. London: Routledge.

Auty, R. (2008) Political Economy of African Mineral Revenue Deployment: Angola, Botswana, Nigeria and Zambia compared. WP 28/2008, Madrid: Real Instituto Elcano.

Azevedo, M.J. (1998) Roots of Violence: A history of the war in Chad. Amsterdam: Gordon and Breach.

Basedau, M. (2005) Context Matters. Rethinking The Resource Curse in Sub-Saharan Africa. GIGA Working Papers, No. 1. Hamburg: German Institute of Global and Area Studies.

Bayart, J.F. (2000) Africa in the World: A History of Extraversion. African Affairs 99(395): 217-267.

Bayart, J.F. (2008) Obscenité Franco-Tchadienne. Le Monde, 18 November.

Beblawi, H. and Luciani, G. (1987) The Rentier State. New York: Croom Helm.

Behrends, A. (2008) Fighting for oil when there is no oil yet: The Darfur-Chad border. European Journal of Anthropology 52:39-56.

BP. (2012) Statistical Review of World Energy. June 2012. Chapter 6: Oil. London: British Petroleum.

Brunnschweiler, C. and Bulte, E. (2008) The resource curse revisited and revised: A tale of paradoxes and red herrings. Journal of Environmental Economics and Management 55: 248-264.

Buijtenhuijs, R. (1998) Chad in the Age of the Warlords. In D. Birmingham and P.M. Martin (eds) History of Central Africa: The Contemporary Years since 1960. London: Longman.

Campos, A. and Micó, P. (2006) Labour and Trade Union Freedom in Equatorial Guinea. Madrid: Fundación Paz y Solidaridad 'Serafín Aliaga' (CCOO).

Carmody, P. (2009) Cruciform soverignty, matrix governance and the scramble for Africa's oil: Insights from Chad and Sudan. Political Geography 28: 353-361.

Carmody, P. (2011) The New Scramble for Africa. Cambridge: Polity Press.

CCFD-Terre Solidaire. (2012) Le développement piégé. Les transferts d'armes et le développement au Tchad (2005-2010). Paris: CCFD-Terre Solidaire.

Collier, P. and Hoeffler, A. (1998) On the Economic Causes of Civil War. Oxford Economic Papers, 50.

Collier, P. and Hoeffler, A. (2004) Greed and Grievance in Civil War. Oxford Economic Papers, 56.

Colom, A. (2010) Lessons from the Failure of Chad's Oil Revenue Management Model. ARI 12/2010. Madrid: Real Instituto Elcano.

Colom, A. (2012) Recursos naturales y desarrollo en el Chad: ¿maldición de los recursos o inserción periférica? Revista de Economía Mundial 31: 81-113.

Cooper, F. (2002) Africa Since 1940: The Past of the Present. New Approaches to African History. Cambridge: Cambridge University Press. 
Corden, W.M. and Neary J.P. (1982) Booming Sector and De-Industrialisation in a Small Open Economy. The Economic Journal 92(368): 825-848.

Cramer, C. (2002) Homo Economicus Goes at War: Methodological Individualism, Rational Choice and the Political Economy of War. World Development 30(11): 1845-1864.

De Waal, A. (2008) Making Sense of Chad. African Arguments http://africanarguments.org/2008/02/04/making-sense-of-chad (accessed 20 March 2013)

Di John, J. (2007) Oil Abundance and Violent Political Conflict: A Critical Assessment. Journal of Development Studies 43(6): 961-986.

EG Justice (2012) UNESCO: Decepción ante resultado de votación sobre Premio Obiang, 9 March. Washington

Escribano, G. (1999) Guinea Ecuatorial: de la Ayuda al Petróleo. Revista Meridiano CERI, 26.

Esteban, M. (2010) A Silent Invasion? African Views on the Growing Chinese Presence in Africa: The Case of Equatorial Guinea. African and Asian Studies 9(3): 232-251.

Fegley, R. (1989) Equatorial Guinea. An African Tragedy. New York: Peter Lang.

Frynas, J.G. (2004) The Oil Boom in Equatorial Guinea. African Affairs 103(413): 542543.

Gary, I. and Karl, T.L. (2003) Bottom of the Barrel: Africa's Oil Boom and the Poor. Washington: Catholic Relief Services.

Gary, I. and Reisch, N. (2004) Le pétrole tchadien: miracle ou mirage? Washington, DC: Catholic Relief Services and Bank Information Center.

Ghazvinian, J. (2007) Untapped. The Scramble for Africa's Oil. London: Harcourt, Inc.

Gibbon, P. (2002) Present-day capitalism, the New International Trade Regime and Africa. Review of African Political Economy 29(91): 95-112.

Global Witness. (2004) Time for Transparency. Coming Clean on Oil, Mining and Gas Revenues. London: Global Witness.

Global Witness. (2009) The Secret Life of a Shopaholic. How an African dictator's playboy son went on a multi-million dollar shopping spree in the U.S. London.

Gould, J. and Winters, M. (2007) An Obsolescing Bargain in Chad : Shifts in Leverage between the Government and the World Bank. Business and Politics 9(2).

Gould, J.A. and Winters, M.S. (2011) Petroleum Blues: the Political Economy of Resources and Conflict in Chad. In P. Lujala and S.A. Rustad (eds) High-Value Natural Resources and Post-Conflict Peacebuilding. Washington: Environmental Law Institute.

Government of Equatorial Guinea. (2006) Ley de Hidrocarburos de la República de Guinea Ecuatorial 8/2006. Malabo: Government of Equatorial Guinea.

Güell, O. (2009) Asaltado el palacio de Obiang en Malabo. El País, 18 February.

Haber, S. and Menaldo, V. (2011) Do Natural Resources Fuel Authoritarianism? A Reappraisal of the Resource Curse. American Political Science Review 105(1): 1-26.

Hansen, K.F. (2011) Military rebels in Chad. Changes since 2008. NOREF Report. Bergen: Norwegian Peacebuilding Centre.

Harel, X. (2006) Afrique, Pillage à Huis Clos. Comment une Pognée d'Initiés Siphonne le Pétrole Africain. Paris: Fayard.

Harrison, G. (2004) The World Bank and Africa: The Construction of Governance States. London: Routledge.

HSBA. (2011) Union des Forces de Résistance. Sudan Human Security Baseline Assessment. 
Human Rights Watch. (2009) Well Oiled. Oil and Human Rights in Equatorial Guinea. New York: Human Rights Watch.

Humphreys, M., Sachs, J. and Stiglitz, J. (2007) Escaping the Resource Curse. New York: Columbia University Press.

IMF. (2011) Investment Objectives of Sovereign Wealth Funds. A Shifting Paradigm. IMF Working Papers, WP/11/19. Washington: IMF.

International Crisis Group (ICG). (2009) Tchad: sortir du piège pétrolier. Briefing Afrique No. 65. Brussels: International Crisis Group.

Karl, T.L. (1997) The Paradox of Plenty: Oil Booms and Petro-States. Berkeley: University of California Press.

Karl, T.L. (2005) Understanding the Resource Curse. In S. Tsalik and A. Schiffrin (eds) Covering Oil. A Reporter's Guide to Energy and Development. New York: Open Society Institute.

Kojucharov, N. (2007) Poverty, Petroleum \& Policy Intervention: Lessons from the Chad-Cameroon Pipeline. Review of African Political Economy 34(113):477-496.

Linigier-Goumaz, M. (1996) Diecisiete años de la dictadura Nguemista, 1979-1996. Estudios de Asia y África 31(3): 645-691.

Magrin, G. (2003) Les enjeux d'un enrichissement pétrolier en Afrique centrale. Le cas $d u$ Tchad. Mémoires et documents de l'UMR Prodig, no 22. Graphigéo, pp. 5-36.

Mahdavy, H. (1970) The Patterns and Problems of Economic Development in Rentier States: The case of Iran. In M.A. Cook (ed) Studies in the Economic History of Middle East. Oxford: Oxford University Press.

Massey, S. and May, R. (2005) Dallas to Doba: Oil and Chad, External Controls and Internal Politics. Journal of Contemporary African Studies 23(2): 253-276.

Massey, S. and May, R. (2006) The Crisis in Chad. African Affairs 105(420): 253-276.

Massey, S. and May, R. (2009) Oil and War in Chad. In R. Southall and H. Melber, op. cit.

McFerson, H. M. (2009) Governance and Hyper-corruption in Resource-rich African Countries. Third World Quarterly 30(8): 1529-1547.

McSherry, B. (2006) The Political Economy of Oil in Equatorial Guinea. African Studies Quarterly 8(3).

Nzang, E. (2009) Wa kobo abe, wa kobo politik: Three Decades of Social Paralysis and Political Immobility in Equatorial Guinea. Afro-Hispanic Review 28(2): 143-162.

Nachega, J-C. and Wieczorek, J. (2012) Chad: Lessons from the Oil Years. In B. Akitoby and S. Coorey (eds) Oil Wealth in Central Africa: policies for inclusive growth. Washington: IMF.

Obi, C. (2009) Scrambling for Oil in West Africa? In R. Southall and H. Melber op. cit.

Open Society. (2009) APDHE vs Obiang Family, 6 February.

Pegg, S. (2005) Can Policy Intervention Beat the Resource Curse? Evidence from the Chad-Cameroon pipeline project. African Affairs 105(418): 1-25.

Pegg. S. (2009) Chronicle of a Death Foretold: The Collapse of the Chad-Cameroon Pipeline Project. African Affairs 108(431): 311-320.

Petry, M. and Bambé, N. (2005) Le pétrole du Tchad. Rêve ou cauchemar pour les populations. Paris: Karthala.

Reno, W. (2000) Africa's Weak States, Nonstate Actors, and the Privatization of Interstate Relations. In J. Harbeson and D. Rothchild Africa in World Politics. The African State System in Flux. Boulder: Westview Press.

Reno, W. (2001) How Sovereignty Matters: International Markets and the Political Economy of Local Politics in Weak States. In T. Callaghy, R. Kassimir and R. 
Latham. Intervention and Transnationalism in Africa. Global-Local Networks of Power. Cambridge: Cambridge University Press.

Reyna, S. (2007) The Traveling Model That Would Not Travel. Oil, Empire, and Patrimonialism in Contemporary Chad. Social Analysis 51(3): 78-102.

Reyna, S. (2011) 'Constituting Domination/Constructing Monsters. Imperialism, Cultural Desire and Anti-Beowulfs in the Chadian Petro-state', in Berhrends, A.; Reyna, S. and Schlee, G. (eds.) Crude Domination. An Anthropology of Oil. New York: Berghahn Books.

Ross, M. (1990) The Political Economy of the Resource Curse. World Politics 51(2): 297-322.

Ross, M. (2001) Does Oil Hinder Democracy? World Politics 53(3): 325-361.

Ross, M. (2004) How do natural resources influence civil war? Evidence from 13 cases. International Organization 58(1): 35-67.

Ross, M. (2009) Oil and Democracy Revisited. University of California-Los Angeles, mimeo.

Sachs, J. and Warner, A. (1995) Natural Resource Abundance and Economic Growth. NBER Working Paper 5398. Cambridge, MA: National Bureau of Economic Research.

Sant, J. (2008) El petróleo y las urnas. Evolución del Estado en Guinea Ecuatorial. Nova Africa 28.

Shaxson, N. (2007) What Caring Neighbors Do. Equatorial Guinea. Virgina Quarterly Review 83(1): 35-47.

Shaxson, N. (2011) Treasure Islands. London: Vintage.

Silverstein, K. (2012) Bipolar Policy on Equatorial Guinea, Foreign Policy, 13 June.

Soares de Oliveira, R. (2007) Oil and Politics in the Gulf of Guinea. New York: Columbia University Press.

Southall, R. and Melber, H. (eds). (2009) A New Scramble for Africa? Imperialism, Investment and Development in Africa. Natal: University of KwaZulu Natal Press.

Sundiata, I. (1990) Equatorial Guinea. Colonialism, State Terror and the Search for Stability, Boulder-San Francisco-Oxford: Westview Press.

The Economist. (1977) The Dutch Disease. The Economist, 26 November: pp. 82-83.

The Washington Post. (2006) With Friends Like These...Condoleezza Rice's inglorious moment, The Washington Post, 18 April.

UNDP. (2011) Human Development Report. New York: United Nations Development Programme.

US Senate. (2004) Money Laundering and Foreign Corruption: Enforcement and Effectiveness of the Patriot Act, Case Study Involving Riggs Bank. Minority Staff of the Permanent Subcommittee on Investigations, 15 July.

Wade, R. (2003) What strategies are viable for developing countries today? The WTO and the shrinking for the 'development space'. Review of African Political Economy 10(4): 621-644.

Wick, K. and Bulte, E. (2009) The Curse of Natural Resources. Annual Review of Resource Economics 1: 139-155.

Winters, M. and Gould, J. (2011) Betting on Oil: The World Bank's Attempt to Promote Accountability in Chad. Global Governance 17: 229-245.

Wood, G. (2004) Business and politics in a criminal state: The case of Equatorial Guinea. African Affairs 103(413): 547-567.

World Bank. (2002) Treasure or Trouble: Mining in Developing Countries. Washington, DC: World Bank. 
World Bank. (2012) World Development Indicators. On-Line edition. Washington, DC: World Bank.

Yates, D.A. (1996) The Rentier State in Africa: Oil Rent Dependency and Neocolonialism in the Republic of Gabon. Trenton: Africa World Press.

Yates, D.A. (2012) The Scramble for African Oil: Oppression, Corruption and War for Control of Africa's Natural Resources. Pluto Press: London. 